\title{
CONCEPTUAL APPROACH \\ TO FORMING ADMINISTRATIVE DECISIONS \\ ON THE STATE REGULATION OF THE REGIONAL HIGHER EDUCATION SYSTEM OF UKRAINE
}

\section{Kocharian I. S.}

\section{INTRODUCTION}

The future of Ukraine, the rise of its economy and culture, the development of democratic principles of the organization of society directly depends on the efforts of the regions. Achievement of the goals determined by the strategies of development of the regional higher education system should be based on creating conditions for solving existing problems in the system of planning and development of the region.

Such an approach, based on science and backed up by historical experience, should become the basis of the current regional policy of Ukraine.

The introduction of political reform in Ukraine fundamentally changed the format of the management system of regional and local development, the division of powers and responsibility for the development of territories.

The accession of Ukraine to the Bologna process objectively requires a more specific direction of the policy of developing the national system of higher education for joining the European space. Regional higher education institutions (HEI) play a leading role in this task, as one of the requirements of the Bologna Declaration is the independence and autonomy of universities in the processes of adaptation of higher education and research systems.

It should be noted that the existing research does not solve the problem of evaluating the links between economic and education development, the adaptive characteristics of education have not been studied, there are no models for education planning, taking into account the lack of training specialists and the needs of employers, there are no adequate models for calculating and forecasting the need for specialists that connect the regional education system and the region's economy, the 
dynamics of demand in the market of educational services is not investigated ${ }^{1}$.

Thus, it can be stated that currently methods and techniques of predicting the labor market and evaluating the needs of participants of the regional labor market in the form of requirements to competences of future specialists are not developed enough. In addition, there is no conceptual scheme according to which the decision-making support system can be implemented with the interaction of the regional education system and the labor market ${ }^{2}$.

New pro-European directions of the development of educational area of Ukraine require the transformation of both the mechanisms of state administration of regional education and the reform of the activities of higher education institutions. Consideration of the situation at the regional level of higher education shows that there are a large number of problems of different nature: state-management, financial, organizational, etc. ${ }^{3}$.

In Ukraine, there is a need to ensure the reality and implementation of the identified goals of strategic development of the regions, using the newest tools of strategic planning and forecasting, as well as to link target strategic milestones to optimization of the costs of resources to achieve them ${ }^{4}$.

\section{Formation of the need of the national economy for specialists with higher education}

Let us analyse some of the main parameters of the type of economic activity "Education" in relation to the HEI of III-IV accreditation levels, listed in Table 1.

The analysis shows that during the period from 1990/91 to 2005/06, the number of HEIs increased by 2.3 times, the number of students - by 2.5 times, and the admission to the first year - by 2.88 times.

\footnotetext{
${ }^{1}$ Мазалова О.Г. Формування системи моніторингу управлінської діяльності органів управління освітою як основи ефективної діяльності регіональної системи управління освітою. URL: http://revolution.allbest.ru

${ }^{2}$ Рамазанов С.К., Крупський К.Л. Розробка концептуальної схеми прийняття рішень при взаємодії регіональної системи освіти та ринку праці. Бізнесінформ. 2012. № 4. С. 154-157.

${ }^{3}$ Щербакова Г.О. Проблеми і особливості державного управління вищою освітою в контексті адаптації діяльності регіональних вищих навчальних закладів до Болонського процесу. URL: http://www.nbuv.gov.ua/e-journals/dutp/20062/txts/GALUZEVE\%5C06sgozbp.pdf

${ }^{4}$ Стратегії розвитку регіонів: шляхи забезпечення дієвості : Збірник матеріалів «круглого столу»/ за ред. С.О. Білої. Київ : НІСД, 2011. 88 с. URL: http://www.niss.gov.ua/content/articles/files/Broshura Bilaa47aa.pdf
} 


\section{Main indicators of higher education institutions of III-IV accreditation levels ${ }^{5}$}

\begin{tabular}{|c|c|c|c|c|}
\hline $\begin{array}{c}\text { Period } \\
\text { (e.y.) }\end{array}$ & $\begin{array}{c}\text { Amount of } \\
\text { institutions }\end{array}$ & $\begin{array}{c}\text { Amount of students } \\
\text { in institutions, } \\
\text { thousand. }\end{array}$ & $\begin{array}{c}\text { Students } \\
\text { accepted, } \\
\text { thousand. }\end{array}$ & $\begin{array}{c}\text { Specialists } \\
\text { graduated, } \\
\text { thousand. }\end{array}$ \\
\hline 1 & 2 & 3 & 4 & 5 \\
\hline $1990 / 91$ & 149 & 881,3 & 174,5 & 136,9 \\
\hline $1992 / 93$ & 158 & 855,9 & 170,4 & 144,1 \\
\hline $1993 / 94$ & 159 & 829,2 & 170,0 & 153,5 \\
\hline $1994 / 95$ & 232 & 888,5 & 198,0 & 149,0 \\
\hline $2000 / 01$ & 315 & 1402,9 & 346,4 & 273,6 \\
\hline $2002 / 03$ & 330 & 1686,9 & 408,6 & 356,7 \\
\hline $2003 / 04$ & 339 & 1843,8 & 432,5 & 416,6 \\
\hline $2004 / 05$ & 347 & 2026,7 & 475,2 & 316,2 \\
\hline $2005 / 06$ & 345 & 2203,8 & $503,0^{1}$ & $372,4^{2}$ \\
\hline $2006 / 07$ & 350 & 2318,6 & $507,7^{1}$ & $413,6^{2}$ \\
\hline $2007 / 08$ & 351 & 2372,5 & $491,2^{1}$ & $468,4^{2}$ \\
\hline $2008 / 09$ & 353 & 2364,5 & $425,2^{1}$ & $505,2^{2}$ \\
\hline $2009 / 10$ & 350 & 2245,2 & $370,5^{1}$ & $527,3^{2}$ \\
\hline $2010 / 11$ & 349 & 2129,8 & $392,0^{1}$ & $543,7^{2}$ \\
\hline $2011 / 12$ & 345 & 1954,8 & $314,5^{1}$ & $529,8^{2}$ \\
\hline $2012 / 13$ & 334 & 1824,9 & $341,3^{1}$ & $520,7^{2}$ \\
\hline $2013 / 14$ & 325 & 1723,7 & $348,0^{1}$ & $485,1^{2}$ \\
\hline $2014 / 15$ & 277 & 1438,0 & $291,6^{1}$ & $405,4^{2}$ \\
\hline $2015 / 16$ & 288 & 1375,2 & $259,9^{3}$ & $374,0^{4}$ \\
\hline $2016 / 17$ & 287 & 1369,4 & $253,2^{3}$ & $318,7^{4}$ \\
\hline $2017 / 18$ & 289 & 1330,0 & $264,4^{3}$ & $359,9^{4}$ \\
\hline
\end{tabular}

* Data for 2014-15 academic year does not take into account the indicators of the temporarily occupied territory of the Autonomous Republic of Crimea, the city of Sevastopol and parts of the zone of ATO.

1 Persons accepted to the initial cycle of study (excluding those accepted for continuing education with a goal of obtaining a higher degree of higher education).

${ }^{2}$ Specialists graduated (excluding those graduated from the relevant cycle of study, in particular Bachelor studies, and continuing their education in order to obtain a higher degree of higher education).

${ }^{3}$ Persons accepted to the initial cycle of study (excluding those accepted for continuing education in order to obtain a higher educational degree (educational qualification level).

${ }^{4}$ Specialists graduated (excluding those who have completed the appropriate cycle of study, in particular Bachelor studies, and continue their education in order to obtain a higher educational degree (educational qualification level) are issued).

\footnotetext{
${ }^{5}$ Статистичний щорічник України за 2017 рік. Державна служба статистики України. URL: https://ukrstat.org/uk/druk/publicat/kat_u/2018/zb/11/zb_seu2017_u.pdf
} 
At first glance, these cardinal changes are positive. But the question arises whether these changes were substantiated, could it be possible to increase the training potential of HEI in such a relatively short period in 2.5-2.88 times without losing the quality of education; Was there a need to increase the academic capacity of admission in 2005/06 e.y. up to 503 thousand students, if already in 2011/12 e.y. its use decreased to 314.5 thousand, in $2014 / 15$ e.y. to 291.6 thousand, and in $2017 / 18$ e.y. to 264.4 thousand, largely due to the demographic crisis. The same can be said about the number of universities that in 2017/19 e.y. decreased by 60 institutions in relation to 2010/11 e.y.

Since the admission of students in amount of 392 thousand (2010/11 e.y.) was supported by a licensed volume, HEIs were equipped with the necessary basic means. This means that in 2017/18 e.y. there was a mismanagement of fixed assets in the amount corresponding to 127.6 thousand of students (392-264.4). With an average financial strength of one student, 12.7 thousand UAH (72520/5730), where 72520 million UAH. is the fixed assets of the type of economic activity "Education" 5730 - the number of people who studied in educational institutions in 2017/18 e.y., thousand people ${ }^{7}$, the cost of fixed assets with forced simplicity, makes 1614 million UAH (assuming the solution of task of evaluating the relation of economic development with the specific capital coefficient of all persons who studied in educational institutions). However, when making the planned decisions on training specialists in 2010/11 e.y., the impact of the demographic crisis has not been taken into account, which has caused negative consequences in higher education.

The negative consequences of rapid, extensive development of the higher education system include:

- the partial use by HEI of the educational capacity in a number of specialties, primarily engineering;

- tendency for the absolute absence of the first-year admission program for licensed specialties of HEI;

- a significant discrepancy between the demand for specialties that are widely popularized or presented to the population as the most "modern", trendy, and capacities of the HEI, in which the training of

\footnotetext{
${ }^{6}$ Статистичний щорічник України за 2013 рік. Державна служба статистики України. URL: http://ukrstat.org/uk/druk/publicat/Arhiv_u/01/Arch_zor_zb.htm

${ }^{7}$ Статистичний щорічник України за 2017 рік. Державна служба статистики України. URL: https://ukrstat.org/uk/druk/publicat/kat_u/2018/zb/11/zb_seu2017_u.pdf
} 
specialists in these specialties is carried out. Because of this discrepancy, HEI failure to fully meet the economic needs for professionals and the social need of the population in higher education is emerging, and, on the one hand, there is a shortage of educational capacities in such specialties and, on the other, significant volumes of "frozen" fixed assets and human resources of HEI, which carry out training in specialties not in demand in the education market;

- overloading the infrastructure of social services of individual cities and the need for additional investments due to the lack of a well-founded state strategy of regional development of the potential of higher education and the choice of applicants for the place of higher education.

The described situation regarding the planning of training of specialists with higher education makes it possible to distinguish the following factors, which significantly influence the efficiency of the system of higher education:

1) additional investment in increasing the educational capacity;

2) additional investments in the development of the infrastructure of the region related to the provision of educational services to residents from other regions during their training in the HEI;

3 ) additional investments in the basic means of the region related to student training and employment of specialists from other regions.

From the point of view of the state budget, it is more profitable for the state to choose such approaches to macroeconomic planning of specialists training that will ensure, with a certain quality of specialists, the least cost of investment, but with observance of the established standard of living of both permanent residents of the region and students during training and their employment after obtaining higher education.

The main purpose of state planning of training specialists is to ensure the needs of economic entities, organizations of various forms and levels for specialists of all specialties. However, apart from ensuring this, other conditions and restrictions, including financial and social ones, should be taken into account when planning a state order.

For example, if the educational capacity of higher education institutions in a certain region of Ukraine is not enough to meet the needs of this region for the specialists of a specific specialty, then the plan offices face the question of choosing a rational variant: to increase the capacity of 
the HEI of the region at the expense of investments or to use free capacities for the training specialists of HEI of other regions.

The choice of the second option ensures savings in investment, but generates a social problem of additional burden on the city's infrastructure due to the additional influx of young people to study in its educational institutions.

It also should be taken into account that some graduates of the HEI remain at permanently residence in the city after graduation, become its full rights residents, and therefore needs the appropriate quality of services for all social systems. Among them, production, trade, transport, communications, education, health care and social assistance, provision of communal and individual services, cultural and sporting activities, and more.

In this case, it is not about the current costs of providing services, which, as a rule, compensates the consumer of these services. It is about the basic means, without which it is impossible to provide these services in both quantitative and qualitative terms. That is, in order to maintain the level of services per person after increasing the number of residents of the city, it is necessary to increase accordingly the fixed assets of the city (region), and consequently, the expenses of the state and local budgets.

Fixed assets - an important component of the national wealth of the country and each region, the city. These include land, buildings, structures, machinery and equipment, vehicles, communication paths, etc.

In the absence of significant changes in the technology of services, one can assume a linear relationship between the volume of products (services) and the value of fixed assets through which these products are produced and services are provided.

For example, if the number of inhabitants of the city increased by $10 \%$ because graduates of institutions of higher education who came from other regions remain in the city, then in order to ensure that the specific number of services per person does not decrease, it is necessary to increase the corresponding fixed assets by $10 \%$. It should be take into account not only the total value of fixed assets, but also the cost of fixed assets per person in the region.

Suppose $B_{r}-$ cost of fixed assets of region $r, P_{r}-$ amount of population of region $r$, then the cost of fixed assets per person in region $r$, is 


$$
b_{r}=\frac{B_{r}}{P_{r}}, r=\overline{1, R},
$$

where $R$ - amount of regions.

Thus, if there is a known number of graduates of HEI remaining in the city of obtaining higher education, then it is possible to determine the additional need for money for the corresponding increase in fixed assets, and this should be taken into account when planning a state order for training specialists.

To some extent, this also applies to students who after achieving higher education leave a place of study for work in other regions. These students - throughout the entire period of study - as well as permanent residents of the city must be provided with communal and individual services. Consequently, it requires adequate funds to increase fixed assets for this period.

We present dependencies for determining the additional burden on state and local budgets in order to maintain a level of fixed assets per person, which will enable not to lower the level of services in connection with the increase in the population of the city. Suppose that the proportion of graduates of HEI who came to study from other regions and remained on a permanent work at the place of study in the region $r$ is $k_{r}$. Then the proportion of specialists who leave the city (region) of training $r$ and go to work in other regions is $1-k_{r} \quad\left(0 \leq k_{r} \leq 1, \forall r\right)$.

The need for additional funds to increase fixed assets, which is associated with an increase in the population of the city $r$ due to the arrival of students from other regions for obtaining higher education, is:

for graduates of HEI who stay for a period of study -

$$
\Phi_{r 1}=k_{r} \cdot b_{r} \cdot x_{r}, r=\overline{1, R},
$$

where $x_{r}$ - the number of students who, in accordance with the state order plan, were enrolled for study at the HEI of $r$ city (region) to meet the needs for specialists of other regions;

for graduates of HEI who, after completing their studies, leave the region $r$ for work in other regions -

$$
\Phi_{r 2}=\left(1-k_{r}\right) \cdot t \cdot E \cdot b_{r} \cdot x_{r}, r=\overline{1, R},
$$

where $t$ - term of studying a student for acquiring higher education, years; 
$E$ - the coefficient of investments efficiency, makes it possible to determine the annual share of the total value of fixed assets. This value is inverse to the payback period of the investment $t_{\text {окуп }}-E=1 / t_{\text {окуп }}$.

Thus, one can determine the general need for funds to build up fixed assets in order to maintain the specific level of services of the city (region) $r$ upon admission to study in its higher educational institutions of students from other regions and meeting their needs in specialists:

$$
\Phi_{\mathrm{r}}=\Phi_{r 1}+\Phi_{r 2}=k_{r} b_{r} x_{r}+\left(1-k_{r}\right) t E b_{r} x_{r}, \quad r=\overline{1, R} .
$$

The first component of the dependence (4) reflects an additional burden on budgets due to an increase in the city's population by the number of specialists who remain on permanent residence after obtaining a diploma.

The second component is a part of the fixed assets that corresponds to the period of training of students who come to study from other regions and leave the city after the completion of studies. The value of $E b_{r}$ represents the value of fixed assets per person per one year. If the training period is, for example, 4 years, then the need to increase the fixed assets will be $4 E b_{r}$ per student.

After the expiration of this term, the need for additional fixed assets disappears. However, the educational process continues after the graduation of the specialists of this category. If the volumes of reception in the future remain at the same level, the need to build up fixed assets continues for the future. It is clear that it should be adjusted depending on the number of students in this category.

The given formulas give an opportunity to calculate the need for building up fixed assets, connected with the increase of the inhabitants of the city because of training of specialists.

But taking into account this factor when forming a plan for government order for the training of specialists should be borne in mind that only a part of fixed assets is intended to provide services for students. Mostly it is a social service such as health care, education, recreation and sports, etc. In this regard, in order to develop a plan for the training of specialists, it is necessary to determine exactly this share of fixed assets.

It should be noted that the identified problem in the increase of fixed assets could be considered not as a plan for increasing the fixed assets and 
the necessary investment in the state budget expenditures, but only as one of the criteria for optimal planning of training orders for specialists taking into account the regional factor ${ }^{8}$.

Since every student has the right to choose a place of study, the state has no direct levers of influence on decision-making by entrants. In this regard, it is advisable for the state to develop policies aimed at providing higher education services to the population with a high quality of training specialists and savings in capital investment in the development of basic infrastructure that is associated with compensation for inappropriate decisions. To form a rational policy in the field of providing educational services is necessary:

to analyze the actual distribution of applicants among the regions for acquiring higher education;

to identify the need for educational capacity building by region;

to determine the share of specialists remaining to work in the region of higher education acquiring;

to determine the specific investment in increasing of the training capacity of HEI;

to determine the specific investments in the basic means of the regions to provide the appropriate level of social services that are related to the training of students from other regions;

to determine the optimal plan for the distribution of entrants between regions on the criterion of minimization of additional investments;

to form a system of informing and encouraging entrants and local government bodies to make decisions that are approaching optimal. The complex of problems of development and improvement of the quality of higher education can not be overcome by solving a specific task or tasks. It requires the development of a comprehensive state policy on the development of a higher education system. However, state policy at the level of central executive bodies and local authorities is often carried out without sufficient justification, and an example of this can be the real development of our higher education system during the last two decades. Among the reasons is the complexity of this system and the lack of substantiation of the measures and decisions that are being taken.

\footnotetext{
8 Кочарян I.C., Безус А.М., Петровська Ю.В. Вплив регіонального фактора на планування державного замовлення на підготовку фахівців. Наук. вісник Академії муніцииального управління : зб. наук. праць. Серія : Економіка. Київ : Академ. муніцип. упр., 2012. Вип. 11. С. 131-137.
} 
To address the listed set of problems that have not been adequately addressed at the level of public administration, an optimization model should be built to help with the formulation and solution of the problem.

\section{Planning of training of specialists and development of higher educational capacities}

The main stages of planning the preparation of specialists in the context of regions and the development of higher education system are shown in Fig. 1 (the notations are listed below in the text).

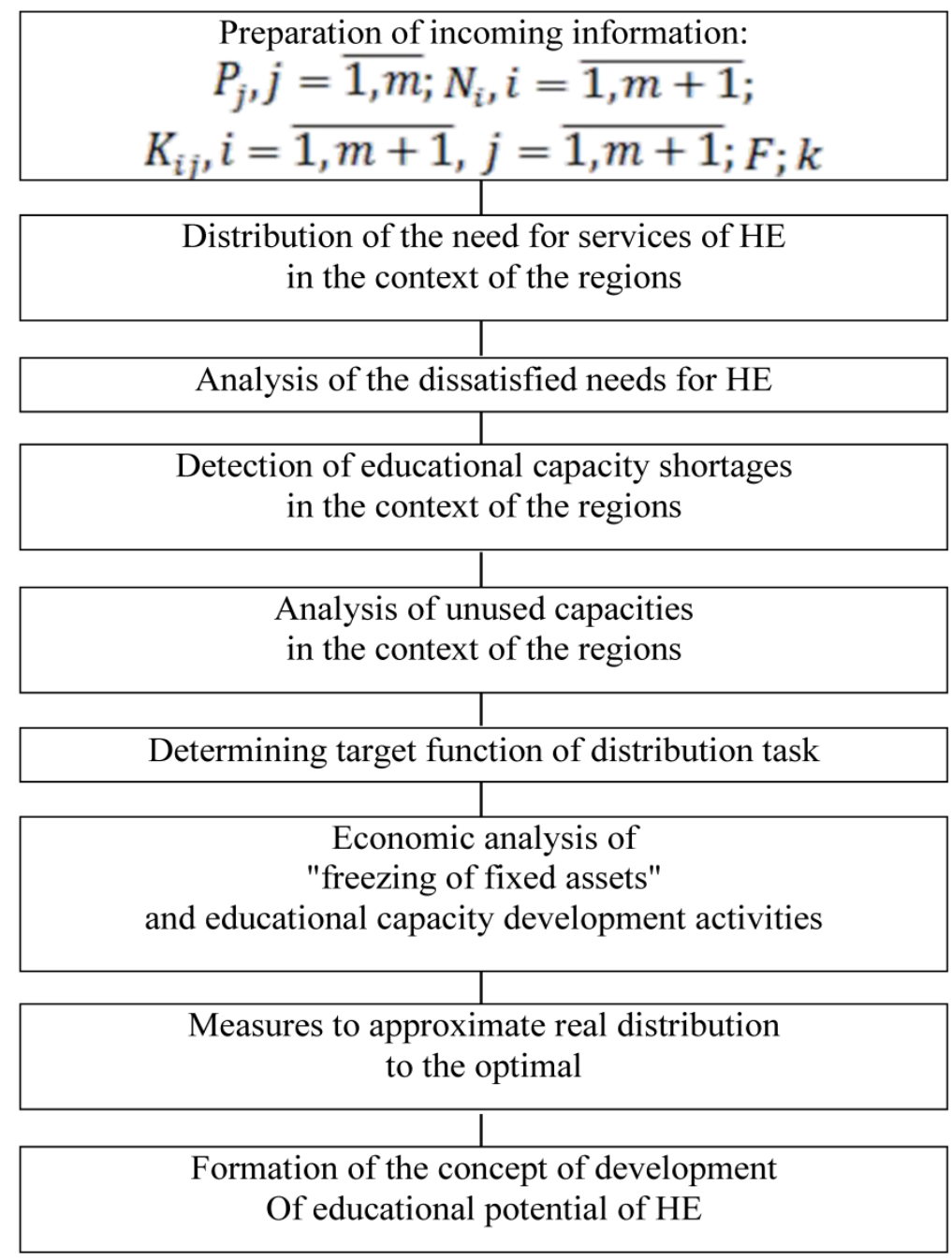

\section{Figure 1. Scheme of realization of distribution of educational services and development of educational capacities ${ }^{9}$}

\footnotetext{
${ }^{9}$ Клименюк М.М., Кочарян І.С. Моделювання планових рішень підготовки фахівців з вищою освітою в регіональному розрізі. Економічний простір : зб. наук. пр. Дніпропетровськ : ПДАБА, 2014. № 84. C. 225-234.
} 
It should be determined such distribution of entrants between regions for acquiring higher education (find unknown values $X_{i j}, i=\overline{1, m}, j=\overline{1, m}$ ), which will ensure the need of each region for higher education acquiring, not exceed the educational capacity of each region, $i, i=\overline{1, m}$, and the total additional investment will be minimal.

To develop an optimization model for the distribution of educational services by regions and identifying reserves and deficit of training capacity, we take the notation:

$i$ - region, HEI of which provide education, $i=\overline{1, m}$;

$j-$ the region from which the entrant goes to acquire higher education to another region, $j=\overline{1, m}$;

$N_{i}$ - educational capacity of providing higher education of HEI of region $i, i=\overline{1, m}$, person/year;

$P_{j}-$ need of region $j$ in acquiring higher education, $j=\overline{1, m}$, person/year;

$F$ - amount of budget funds for additional investments, thousand $\mathrm{UAH}$;

$k_{i j}$ - the need for additional investments in the development of educational capacities (at their deficit) and the infrastructure of social services in case of the transfer of the entrant to study from the region $j$ to region $i$ thousand/person;

$m+1$ - fictitious region, introduced in case of shortage of training capacity (additional line) or its incomplete loading (additional column).

$X_{i j}$ - the number of people who moved to the $i$ region from $j$ region to acquire higher education, persons.

Let us make a model of this task.

Target function:

$$
\sum_{i=1}^{m} \sum_{j=1}^{m} k_{i j} X_{i j} \rightarrow \min .
$$

Restrictions on meeting the needs of each region for acquiring higher education:

$$
\sum_{i=1}^{m} X_{i j} \geq P_{j}, j=\overline{1, m}
$$


Limitations on non-exceedence of training capacity in each region:

$$
\sum_{j=1}^{m} X_{i j} \leq N_{i}, i=\overline{1, m} .
$$

Budgetary constraint on additional investment:

$$
\sum_{i=1}^{m} \sum_{j=1}^{m} k_{i j} X_{i j} \leq F .
$$

Conditions of reality (integrality) of the distribution plan:

$$
X_{i j} \geq 0, i=\overline{1, m} ; j=\overline{1, m} \text {. }
$$

To implement the presented linear programming problem, it is necessary to make $m$ constraints to meet the needs of each of the $m$ regions, $m$ constraints of the learning capacities of the HEI of each region, to make the matrix $(m \times m)$ of the specific investment, and to determine $(m \times m)$ unknown values $\mathrm{X}_{i j}$, which will represent optimal solution to the problem ${ }^{10}$.

The primary source of information on the need for economics in specialists is the enterprises, institutions and organizations of each region. The social need of each region's population for higher education is determined by forecasting using the most appropriate functions built on statistical information.

For the formation of restrictions on the training capacities of the $N_{i}$ HEI of each region, the amount of capacity of all HEI located in the corresponding region is determined. The system of monitoring of educational capacities, using information technologies, allows to obtain a plurality of indicators $N_{i}$ for each region, $i=\overline{1, m}$.

The preparation of information on specific additional investment is more complicated and requires prior calculations and substantiation because it depends on the region where the specialist is trained, the region from which they moved, whether there is a shortage of educational capacity in the region, or a trained specialist remains for permanent residence at the place of education, as well as the size of the main assets of the region per person and the structure of these assets.

${ }^{10}$ Клименюк М.М., Кочарян І.С. Моделювання планових рішень підготовки фахівців 3 вищою освітою в регіональному розрізі. Економічний простір : зб. наук. пр. Дніпропетровськ : ПДАБА, 2014. № 84. C. $225-234$. 
Perform calculations to determine the set of norms of specific investment depending on the situations that occur when solving the problem.

Situation 1: $X_{(m+1)}>0, j=\overline{1 . m}$; there is a shortage of training capacity in the region $i$.

This means that in order to prepare one specialist from this set, it is necessary to increase the educational capacity that is to make the corresponding investments in the fixed assets of higher education. We accept these specific costs at the level of the value of fixed assets of the type of economic activity "Education" in the country.

Suppose $K_{\text {осв }}$ - the cost of fixed assets "Education", $S_{\text {осв }}-$ the number of persons studying in higher education institutions, then the financial strength of one student is:

$$
k_{\text {осв }}=\frac{K_{\text {осB }}}{S_{\text {осв }}} .
$$

Thus, $k_{i j}$ for the situation under consideration,

$$
k_{i j}=k_{\text {осв }}\left(1+f_{\text {осв }}\right) ; i=m+1 ; j=\overline{1, m} \sum_{i=1}^{m} X_{i j}<P_{j} \mid,
$$

where $f_{\text {осв }}$ - the degree (coefficient) of the drift of fixed assets in the form of economic activity "Education". This coefficient $f_{\text {осв }}=0,427$ with total drift of fixed assets of Ukraine $f=0,581^{11}$.

Situation 2: $X_{i j}>0, i \neq j$; in region $i, i=\overline{1, m}$, entrants arriving from other regions $j, j=\overline{1, m} \mid i \neq j$, for period of acquiring heigher education. Stay of students from other regions during study should not reduce the level of social services for both residents of the region and temporary students. In this regard, proportional investment in fixed assets is required, which is the material basis for the provision of social services.

Here are some types of economic activity that provide such services and their fixed assets (Table 2).

Since the degree of drift of fixed assets for different types of economic activity is significantly different, it should be taken into account when determining additional investments in fixed assets.

11 Статистичний щорічник України за 2017 рік. Державна служба статистики України. URL: https://ukrstat.org/uk/druk/publicat/kat_u/2018/zb/11/zb_seu2017_u.pdf 
Table 2

Fixed assets by type of economic activity related to the provision of services to the population (on 2016, million UAH) ${ }^{12}$

\begin{tabular}{|c|l|c|c|}
\hline $\begin{array}{c}\text { № } \\
\Pi / \Pi\end{array}$ & \multicolumn{1}{|c|}{ Type of economic activity } & $\begin{array}{r}\text { The cost of } \\
\text { fixed assets }\end{array}$ & $\begin{array}{c}\text { Degree of } \\
\text { drift, \% }\end{array}$ \\
\hline 1. & Building & 72810 & 36 \\
2. & $\begin{array}{l}\text { Temporary accomodation and } \\
\text { organization of food }\end{array}$ & 29772 & 41,9 \\
3. & Transport, warehousing, postal and & 1562079 & 50,6 \\
4. & courier activities & 94243 & 55,6 \\
5. & Activity in the field of administrative and & 1173933 & 80,2 \\
6. & support services & 3596 & 42,7 \\
7. & Education & 21245 & 53,4 \\
8. & Arts, sports, entertainment and recreation & 20901 & 39,2 \\
\hline \multicolumn{2}{|c|}{ Total } & $\mathbf{2 9 7 8 6 5 1}$ & \\
\hline
\end{tabular}

Denote the type of economic activity through $l$, fixed assets of $l$ type $K_{l}$, drift degree $f_{l}$.

Then the cost of fixed assets will be:

$$
K_{l}^{\prime}=K_{l}\left(1+f_{l}\right), l=\overline{1,8},
$$

all types of activities:

$$
K^{\prime}=\sum_{l=1}^{8} K_{l}\left(1+f_{l}\right)
$$

Specific value of fixed assets of the considered types of activities per person

$$
k=\frac{K^{\prime}}{S},
$$

where $S$ - population amount, $S=42,4$ million persons ${ }^{13}$.

12 Статистичний щорічник України за 2017 рік. Державна служба статистики України. URL: https://ukrstat.org/uk/druk/publicat/kat_u/2018/zb/11/zb_seu2017_u.pdf

${ }^{13}$ Статистичний щорічник України за 2017 рік. Державна служба статистики України. URL: https://ukrstat.org/uk/druk/publicat/kat_u/2018/zb/11/zb_seu2017_u.pdf 
Thus, for situation 2:

$$
k_{i j}=k, i=\overline{1, m} ; j=\overline{1, m} \mid i \neq j .
$$

Situation 3: from a set of students of situation $2, x_{i j}>0, i \neq j$, some of them after receiving higher education in the region $i$ remains for permanent residence. If the consolidated costs for the training period for the situation 2 were:

$$
K_{3 \mathrm{~B}}=t E \sum_{i j} k_{i j} x_{i j}
$$

Where $t$ - period of student's studying, years;

$E$ - the normative coefficient of investments efficiency, then the costs in the situation 3 are:

$$
K_{c o u}=\sum_{i, j} k_{i j} x_{i j} .
$$

Data given by Table 2, gives the opportunity to calculate the value of fixed assets of those types of economic activities intended to provide direct social services to the population, as well as the share of fixed assets of these activities in the total value of the country's fixed assets:

$$
k_{0}=\frac{K}{K_{0}}
$$

Where $K$ - the cost of fixed assets of shown in Table 2 types of economic activity;

$K_{0}$ - total cost of fixed assets of the national economy of the country;

$$
\begin{gathered}
K=\sum_{l=1}^{8} K_{l}=2978651 \text { million } \mathrm{UAH} \\
K_{0}=8177408 \text { million } \mathrm{UAH}^{14}
\end{gathered}
$$

Thus, the share of fixed assets of the above types of economic activity is (formula (18))

$$
k_{0}=\frac{2978651}{8177408}=0,37 \text {. }
$$

14 Статистичний щорічник України за 2017 рік. Державна служба статистики України. URL: https://ukrstat.org/uk/druk/publicat/kat_u/2018/zb/11/zb_seu2017_u.pdf 
The above is a calculation of specific investment per student and resident based on the average capital of the country. These norms can be specified by taking into account the indicators of capital in each region:

$$
K_{\mathrm{i}, \text { соц }}=k_{0} K_{i}, i=\overline{1, m} \text {, }
$$

where $K_{i}$ - fixed assets of region $i$, then take into account the degree of their drift in each region

$$
K_{i, \text { соц }}^{\prime}=K_{i, \text { соц }}\left(1+f_{i}\right), i=\overline{1, m},
$$

where $f_{i}$ - the degree of drift of fixed assets of region $i$.

Present a matrix model of distribution of educational services, analysis and development of educational capacities of the higher education system (Table 3).

Table 3

Matrix model of service distribution for acquiring higher education in terms of regions

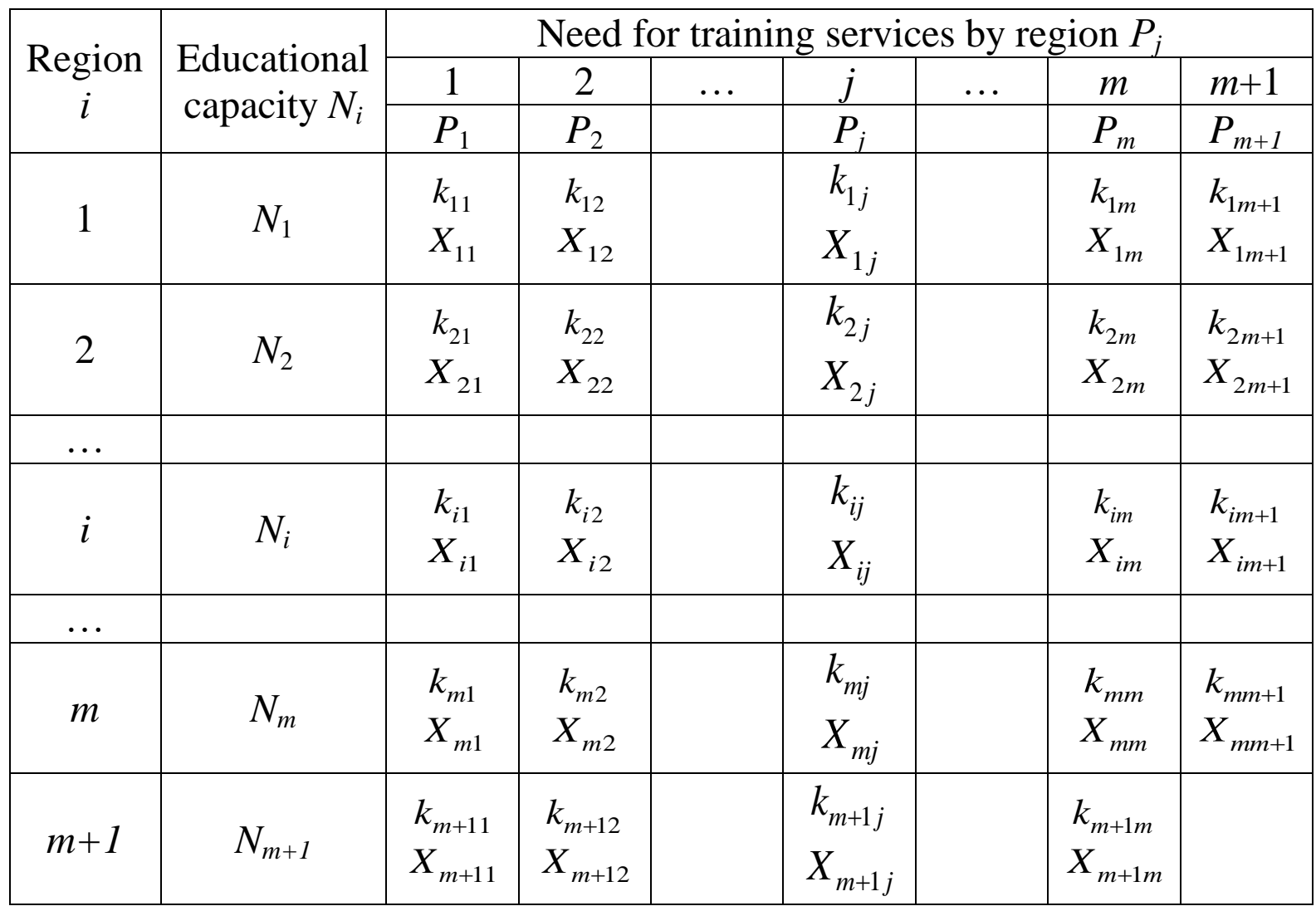

The given model presents the input information: 
$i, j-$ index of region, $i, j=\overline{1, m}$, and the region that provides educational services is $i$, and the one who needs them $-j$;

$P_{j}$ - the need for educational services in the region $j, j=\overline{1, m}$;

$N_{i}$ - educational capacity of the region $i$ of providing higher education, $i=\overline{1, m}$, person;

$k_{i j}$ - specific investment in obtaining a higher education by a student who has moved from region $j$ to region $i$, thousand UAH / person.

The matrix also indicates unknown values that need to be found when solving the problem: $\mathrm{X}_{i j}$ - amount of students of region $j$, who acquire higher education in region $i, i=\overline{1, m} ; j=\overline{1, m}$.

For each region $j$ introduce a set of regions that have learning power, but for the above reasons are excluded from the distribution. Denote this set $I_{j}$; such sets can exist for any region $j$, ie $I_{j}, j=\overline{1, m}$.

Present these sets:

$$
\left.I_{j}=\left\{i \epsilon(\overline{1, m})\left|k_{i j}\right\rangle\right\rangle k_{\text {сон }}\right\}, \mathrm{j}=\overline{1, \mathrm{~m}} .
$$

Present dependencies for determining specific investments for different situations of distribution of services among the regions for the solution of the main task:

$$
k_{i j}=\left\{\begin{array}{l}
k_{\mathrm{coц}}, i \in\left(\overline{1, m)} \mid i \neq j ; i \notin I_{j}, j=\overline{1, m ;}\right. \\
k, i \in I_{j}, j=\overline{1, m} ; \\
0, i=j, i=\overline{1, m} ; j=\overline{1, m} ; \\
k_{\mathrm{ocB}}, \mathrm{i}=\mathrm{m}+1 ; \mathrm{j}=\overline{1, \mathrm{~m}} \\
0, j=m+1 ; i=\overline{1, m} .
\end{array}\right.
$$

Depending on the ratio of educational capacity and the need for higher education, to convert an open task into a closed model, it is necessary to introduce a fictitious line $m+1$ that "takes" all the dissatisfied needs of the regions in higher education, or the fictitious column $m+1$, in which, as a result of the optimal solution to the problem, will be reflected all unused educational capacity of the regions.

The value of fictitious educational capacity $N_{m+1}$ (row $m+1$ ) and fictitious need for educational services $P_{m+1}$ (fictitious column) taking into 
account the exclusion of certain combinations of regions (sets $I_{j}, j=\overline{1, m}$ ) can be determined:

$$
\begin{gathered}
N_{m+1}=\sum_{j=1}^{m}\left(P_{j}-\sum_{i \notin I_{j}} X_{i j}\right) ; \\
P_{m+1}=\sum_{i=1}^{m}\left(N_{i}-\sum_{j=1}^{m} X_{i j} \mid i \notin I_{j}\right) .
\end{gathered}
$$

Here are examples of calculations of specific investments on real statistics. The matrix (Fig. 2) states that to solve the problem need to be prepared $(m+1) \cdot(m+1)$ coefficients $k_{i j}$ of investment costs.

As can be seen from the formula (23), $k_{i j}$ can acquire different values depending on the conditions.

Specific capital investments in fixed assets $k_{\text {соц }}$ types

of economical activities (TEA), providing social services

The cost of fixed assets $K$ of these types of economic activity (Table 2) is $K=2978651$ million UAH; total cost of fixed assets of the national economy $K_{0}=8177408$ million UAH, thus, share of TEA, that are considered is $k_{0}=0,37$.

Given the drift $(f=0,581)$ the cost of fixed assets, which are intended to provide services on average per country:

$$
K_{\text {соц }}=k_{0} K_{0}(1+f)=0,37 \cdot 8177408 \cdot 1,581=4783538 \text { million UAH. }
$$

Specific investments for maintenance of social services for the population at the basic level (per person):

$$
k_{\text {cou }}=\frac{K_{c o u}}{\mathrm{~S}}=\frac{4783538}{42,4}=114 \text { thousand UAH. }
$$

These indicators are used as coefficients for those cells of the matrix (Fig. 2) $m \times m$, where $i \neq j$ and $i \notin I_{j}, j=\overline{1, m}$.

Specific capital investments in fixed assets

of higher education institutions

If while solving the problem remains the dissatisfied need for acquiring higher education, this will be reflected in the line $m+1$. To meet 
this need, additional investment is needed to increase the educational capacity of educational institutions.

The cost of fixed assets of the TEA "Education":

$K_{\text {осв }}=72520$ million $\mathrm{UAH}$; the number of people studying in educational institutions $S_{\text {осв }}=5730$ thousand person. The cost of fixed assets per person is $k_{\mathrm{ocB}}^{\prime}=K_{\text {oсв }} / S_{\text {oсB }}=72520 / 5730=12,7$ thousand UAH, taking into account the drift of fixed assets (coefficient of drift in NED "Education" $f_{\text {осв }}=0,427$.

$$
k_{\text {ocB }}=k_{\text {ocB }}^{\prime}\left(1+f_{\text {ocB }}\right)=12,7(1+0,427)=18,1 \text { thousand UAH. }
$$

Standards $k_{i j}$, placed in the cells of the matrix on the main diagonal, ie $i, j=\overline{1, \mathrm{~m} \mid i=j}$, equal to zero: $k_{i j}=0$.

For cells of the matrix, which should be excluded from the distribution according to the choice of entrants, that is for all $i \in I_{j}, j=\overline{1, m}: k_{i j}=k=k_{\text {cou }}+c$, where $\mathrm{c}-\mathrm{a}$ large number.

Set of values $X_{i j}, i=\overline{1, m}, j=\overline{1, m}$ reflects the optimal distribution of entrants by region for acqiring higher education.

Set of values $X_{i m+1}, i=\overline{1, m}$ reflects the unused teaching capacity of HEI by region in the optimal plan.

Values $X_{m+1 j}, j=\overline{1, m}$ reflect unmet needs in higher education by region.

Target function determines the total amount of capital investment in fixed assets to maintain the level of social services and in the fixed assets of the TEA "Education" and is equal to:

$$
K=\sum_{i=1}^{m+1} \sum_{j=1}^{m+1} k_{i j} X_{i j} .
$$

Including investments in the social and domestic field:

$$
K_{\text {cou }}=\sum_{i=1}^{m} \sum_{j=1}^{m+1} k_{i j} X_{i j} ;
$$

in the field of education:

$$
K_{\text {ocs }}=\sum_{j=1}^{m} k_{m+1 j} X_{m+1 j} .
$$


Unused training capacity

$$
N=\sum_{i=1}^{m} X_{i m+1}
$$

Unmet needs for higher education

$$
P=\sum_{j=1}^{m} X_{m+1 j} .
$$

\section{CONCLUSIONS}

Thus, an important step in adopting an effective policy for the development of the system of higher education is the complex setting of the task of distributing and loading of educational capacities in the context of regions, identifying their reserves, the volume of dissatisfied needs for services for higher education acquiring, which will be the basis for the formation of a state policy for the development of the system of higher education. Thus, an important step in adopting an effective policy for the development of the system of higher education is the complex setting of the task of distributing and loading of educational capacities in the context of regions, identifying their reserves, the volume of dissatisfied needs for services for higher education acquiring, which will be the basis for the formation of a state policy for the development of the system of higher education. Implementation of this approach will allow maintaining an adequate level of social services in the given region with an increase in the number of graduates in it. In addition, such approach is aimed at making the most of the existing training capacity of each region, and the accepted optimality criterion will ensure minimal investment from the state budget. It is advisable to use when developing strategic measures to improve macroeconomic planning and may be the basis for managerial decisions on state regulation of higher education.

\section{SUMMARY}

The decision of the problem of the analysis of the use of educational potential and the development of the system of higher education provides an opportunity to obtain the optimal plan for the criterion of minimization of total investments, which is the basis for making effective decisions on state regulation of development and improvement of the system of higher education. 


\section{REFERENCES}

1. Мазалова О.Г. Формування системи моніторингу управлінської діяльності органів управління освітою як основи ефективної діяльності регіональної системи управління освітою. URL: http://revolution.allbest.ru

2. Рамазанов С.К., Крупський К.Л. Розробка концептуальної схеми прийняття рішень при взаємодії регіональної системи освіти та ринку праці. Бізнесінформ. 2012. № 4. С. 154-157.

3. Щербакова Г.О. Проблеми i особливості державного управління вищою освітою в контексті адаптації діяльності регіональних вищих навчальних закладів до Болонського процесу. URL: http://www.nbuv.gov.ua/e-journals/dutp/20062/txts/ GALUZEVE\%5 C06 sgozbp.pdf

4. Стратегії розвитку регіонів: шляхи забезпечення дієвості : Збірник матеріалів «круглого столу» / за ред. С.О. Білої. Київ : НІСД, 2011. 88 c. URL: http://www.niss.gov.ua/content/articles/files/Broshura_ Bila-a47aa.pdf

5. Статистичний щорічник України за 2017 рік. Державна служба статистики України. URL: https://ukrstat.org/uk/druk/publicat/ kat_u/2018/zb/11/zb_seu2017_u.pdf

6. Статистичний щорічник України за 2013 рік. Державна служба статистики України. URL: http://ukrstat.org/uk/druk/publicat/ Arhiv_u/01/Arch_zor_zb.htm

7. Кочарян I.C., Безус А.М., Петровська Ю.В. Вплив регіонального фактора на планування державного замовлення на підготовку фахівців. Наук. вісник Академії муніципального управління : зб. наук. праць. Серія : Економіка. Київ : Академ. муніцип. упр., 2012. Вип. 11. С. 131-137.

8. Клименюк М.М., Кочарян I.С. Моделювання планових рішень підготовки фахівців з вищою освітою в регіональному розрізі. Економічний простір : зб. наук. пр. Дніпропетровськ : ПДАБА, 2014. № 84. C. 225-234.

Information about the author: Kocharian I. S. Doctor of Economic Sciences, Associate Professor, First Vice-Rector of Kyiv National Karpenko-Karyi University of Theatre, Cinema and Television 